\title{
PENDIDIKan selerai PeRKembangan budaya MAKAN DALAM RUMAH TANGga URBAN JAKARTA PADA PERIODE 1950-AN
}

\section{EDUCATION OF TASTE: THE DEVELOPMENT OF FOOD'S CULTURES IN JAKARTA URBAN HOUSEHOLD IN 1950S PERIOD}

\author{
Gregorius Andika Ariwibowo \\ Balai Pelestarian Nilai Budaya Bandung (BPNB Bandung) \\ JL. Cinambo No.136 UjungBerung-Bandung 42094 \\ Email: andikaariwibowo@gmail.com
}

\begin{abstract}
Abstrak
Periode 1950-an secara global disebut sebagai abad atom. Pada periode ini terjadi modernisasi dalam gaya hidup dengan berkembangnya peralatan-peralatan elektronik dalam lingkup rumah tangga. Pada periode ini pula masyarakat Perkotaan Jakarta mengalami transformasi dalam lingkup rumah tangga, perkembangan peralatan rumah tangga modern mengubah kebiasaan sehari-hari kehidupan rumah tangga perkotaan.. Tulisan ini membahas bentuk gaya hidup masyarakat Perkotaan Jakarta terutama terkait dengan perkembangan budaya makan di lingkungan rumah tangga. Selain itu tulisan ini juga membahas mengenai kebijakan dari pemerintah yang turut memberikan warna dalam perkembangan budaya makan di lingkungan rumah tangga perkotaan. Kajian ini menggunakan konsep Pendidikan selera. Pendidikan selera merupakan proses pengenalan dan perkembangan sajian, selera, dan budaya makan akibat persinggungan dan asosiasi antarbudaya, serta perkembangan budaya modern. Kajian ini menarik kesimpulan bahwa terdapat empat faktor memengaruhi perkembangan budaya makan di Kota Jakarta pada periode 1950-an. Faktor-faktor tersebut yakni, perkembangan pendidikan; interaksi sosial dan kekerabatan yang terjalin antarrumah tangga urban; perkembangan industri pengolahan makanan; dan melalui peran Lembaga Makanan Rakjat (LMR).
\end{abstract}

Kata kunci: Budaya Makan, Masyarakat Urban, Jakarta.

\section{Abstract}

In the 1950s period was globally referred as an atom century. This period witnessed the modernization of lifestyle with the development of electronic equipment in the domestic sphere. In this period the people of Urban Jakarta also undergone a transformation in the domestic sphere, the development of modern household appliances which was changed the habits of everyday life of urban households. This paper discusses the shape of people's lifestyles of Urban Jakarta primarily associated with the development of the culture of eating in a domestic environment. In addition, this paper also discusses the policies of the government that also provide the variety in the development of eating culture in the neighborhood of urban households. This study uses the concept of Education tastes. Taste of education is a process of introduction and development of the dish, tastes and culture of eating due to the intersection and inter-cultural associations, as well as the development of modern culture. This study draws the conclusion that there were four factors that was influencing the development of the culture of eating in the city of Jakarta in the 1950s. These factors were the development of education; social interaction and kinship that exists between urban households and the development of food processing industry; and through the role of the People's Institute of Food (LMR).

Keywords: eating culture, urban society, Jakarta. 


\section{A. PENDAHULUAN}

Memasuki tahun 1950-an terjadi perkembangan budaya makan dan sajian makanan di lingkungan rumah tangga urban di Jakarta. Konstruksi identitas dan budaya pada masyarakat perkotaan yang tumbuh seiring dengan kesadaran nasionalisme dan perkembangan zaman atom telah membuat terjadinya pergeseran pada struktur sosial dan budaya masyarakat. Masyarakat perkotaan Jakarta pada periode 1950-an merupakan masyarakat yang sangat menarik, sebab mereka berusaha menyesuaikan diri mereka dengan perkembangan gaya hidup barat, namun di sisi yang lain mereka membangun identitas diri berdasarkan jiwa nasionalisme dan revolusi.

Studi ini menggunakan konsep education of taste (pendidikan selera) (Ariwibowo, 2011). Education of taste atau pendidikan selera merupakan suatu proses pengenalan dan perkembangan sajian, selera, dan budaya makan akibat persinggungan dan asosiasi antarbudaya, serta perkembangan budaya modern. Education of taste dapat dikatakan sebagai suatu proses pembiasaan lidah terhadap sajian makan yang berasal dari luar lingkungan sajian makan sehari-hari yang telah menjadi kebiasaan dalam masyarakat. Pendidikan selera berkembang karena adanya keinginan dalam masyarakat untuk membiasakan lidah mereka terhadap sajian-sajian makanan baru bagi lidah mereka. Modernisme yang menyebabkan terjadinya perkembangan sajian makanan yang praktis dan efisien, perkembangan eksotisme sajian makanan akibat perkembangan budaya mewah, adaptasi terhadap lingkungan alam, dan penyesuaian terhadap kondisi sosial kultural masyarakat menjadi pendorong proses education of taste (Ariwibowo, 2011: 262-264).

Salah satu unsur budaya yang berada di luar tujuh unsur kebudayaan adalah tradisi makan dan sajian makanan. ${ }^{1}$ Tradisi makan merupakan bagian dari kebudayaan manusia. Makanan bukan hanya sekedar pemenuhan kebutuhan hidup, namun lebih jauh makanan menunjukkan identitas, nilai, moral, kemajuan, dan kualitas suatu masyarakat, bahkan lebih jauh menunjukan status sosial. Makanan dengan simbol dan media pendukungnya seperti sikap (manner), perlengkapan (sendok, garpu, meja, kursi, dan lainnya), sajian, komoditi, dan hal lain yang berkaitan, telah menciptakan identitas budaya dalam masyarakat (Ong Hok Ham, 2009: 137).

Modernisme yang terjadi di Indonesia pada periode 1950-an berkembang seiring dengan munculnya kelas sosial baru yakni masyarakat kelas menengah yang terdiri atas para mahasiswa, pegawai perusahaan asing, pegawai negeri, dan pengusaha, serta masuknya berbagai informasi dan teknologi yang berkembang pada periode ini melalui peran media massa. Meskipun kondisi sosial, ekonomi, dan politik di Indonesia tidak terlalu baik pada masa periode ini, namun tuntutan kelas menengah baru ini akan gaya hidup modern cukup tinggi. Hal ini sangat beralasan sebab latar pendidikan, akses informasi, dan pendapatan yang mereka raih di dalam negara yang masih baru ini cukup lumayan, sehingga mereka memiliki modal budaya untuk menerapkan gaya hidup modern dan barat dari sumbersumber kekayaan yang mereka miliki. Distribusi kekayaan baru inilah yang pada akhirnya menciptakan suatu bentuk hirarki baru dalam masyarakat yang disimbolkan oleh kemewahan di satu sisi dan kemiskinan di sisi yang lain (Vickers, 2004: 116).

Perkembangan media massa dan radio pada periode 1950-an juga memainkan peran penting dalam

\footnotetext{
1 Tujuh unsur kebudayaan: bahasa, peralatan dan kelengkapan hidup, mata pencarian dan ekonomi, sistem kemasyarakatan, kesenian, ilmu pengetahuan dan religi (Djoko Soekiman, 2000: 43).
} 
perkembangan modernisme pada periode ini. Melalui media massa dan radio para kelompok kelas menengah ini dengan mudah mampu mengakses hal-hal baru terutama terkait dengan mode, perlengkapan dan gaya hidup yang berkembang di barat. Dalam kajiannya Adrian Vickers juga mencatat bahwa pada periode ini masyarakat kelas menengah perkotaaan, terutama di Jakarta juga membangun hunian mereka seperti dengan hunian-hunian yang ada di daerah-daerah suburban barat, seperti di kawasan Menteng dan Kebayoran Baru. Hunianhunian baru ini juga dilengkapi oleh beragam fasilitas modern dan mewah (Vickers, 2004: 127).

Membahas kehidupan rumah tangga di perkotaan Jakarta pada peride 1950-an merupakan sesuatu yang sangat menarik. Rumah tangga menjadi media yang sangat mudah untuk menyaksikan berbagai pergeseran gaya hidup, identitas, dan perilaku yang terjadi dalam masyarakat. Dalam rumah tangga terlihat peran-peran yang dimainkan individu untuk menyesuakan diri dengan perkembangan kehidupan sosio-kultural yang terjadi dalam masyarakat. Kehidupan rumah tangga modern pada periode 1950-an berusaha menyesuaikan diri dengan perkembangan zaman atom yang mendasarkan diri dengan perkembangan teknologi, serta perkembangan budaya barat yang ringkas dan efektif. Setiap rumah tangga perkotaan Jakarta, terutama dari kalangan kelas menengah pada periode itu berusaha untuk menerapkan dan mengafirmasikan budaya baru ini dengan kondisi keuangan mereka (Vickers, 2005, 126-128).

Dari perkembangan kapitalisme dalam skala ruang dan kebudayaan maka memunculkan kota dan budaya urban sebagai suatu tahap akhir dari evolusi hirarki dan stratifikasi sosial. ${ }^{2}$ Di dalam

2 Braudel berpendapat bahwa struktur dan hirarki sosial di Eropa dapat dibagi dalam lima tahap. Pertama, pada tingkat paling awal adalah seignorial society, yakni hubungan sosial kota inilah terdapat simbolisasi-simbolisasi dari hadirnya suatu bentuk diferensiasi sosial berdasarkan ekonomi pasar, namun dalam bentuk yang lain kota juga menampilkan suatu pluralisme kebudayaan yang sangat luar biasa dari interaksi antarbudaya dan kelas sosial yang ada di dalamnya.

Perkembangan identitas nasional, hadirnya teknologi, dan proses pembaratan, pada periode 1950-an mengakibatkan penyesuaian tradisi budaya makan dan sajian makanan pada lingkungan rumah tangga urban di Jakarta. Selanjutnya muncul pertanyaan bagaimanakah proses perkembangan budaya makan dan sajian makanan di tengah berbagai dinamika kehidupan sosial, ekonomi, dan budaya pada periode 1950-an?. Perkembangan kondisi ekonomi, sosial, dan budaya pada periode 1950-an telah menyebabkan terjadinya pergeseran gaya hidup dalam masyarakat urban di Jakarta. Studi ini membahas mengenai budaya makan dan sajian makanan sebagai bagian dari gaya hidup baru, serta menjadi elemen untuk melihat perubahan dalam kondisi sosio kultural masyarakat urban Jakarta.

Makanan sebagai bagian dari kajian ilmu budaya. Hal ini karena kajian budaya makan mampu melihat keterkaitan dan ketersinggungan antara makanan dan budaya makan dengan unsur budaya lain,

antara tuan tanah dan para petani yang mengolah tanahnya. Kedua, adalah theocratic society, yakni adalah struktur hirarki dalam institusi gereja Katolik. Ketiga, adalah younger society, yakni munculnya feodalisme yang masih sederhana dengan terbentuknya dinastidinasti keluarga dalam struktur masyarakat Eropa. Keempat, yaitu feudal society, masyarakat feodal diartikan sebagai penggabungan dari keluarga-keluarga dalam younger society ke dalam bentuk monarki. Dan kelima adalah urban society, yakni dengan hadirnya kota dalam membentuk hirarki sosial yang lebih didasarkan pada modernisme (Braudel, 1980: 464-465). 
terutama ketika dikaitkan dengan kajian sejarah kehidupan sehari-hari.

\section{B. METODE PENELITIAN}

Studi mengenai "Perkembangan Budaya Makan dalam Lingkungan Rumah Tangga Urban Jakarta pada 1950-an" akan melihat perkembangan masyarakat pada periode tersebut melalui pendekatan metode sejarah (penentuan tema, pengumpulan sumber, kritik sumber, dan historiografi) dengan lebih menekankan pada penelusuran terhadap kajian media massa yang membahas tema terkait. Alasan ini diambil, sebab sumber ini dapat merepresentasikan kehidupan sehari-hari dan rutinitas masyarakat pada periode 1950-an. Sumber ini merekam mengenai realita dan ornamen-ornamen kehidupan dalam masyarakat, terutama untuk menemukan makna simbolis dari pengaruh peradaban material dalam masyarakat. Media massa yang digunakan antara lain beberapa majalah perempuan seperti "Wanita" dan "Huisvrouw in Indonesie". Kedua majalah perempuan ini digunakan sebab mampu menampilkan elemen dari kehidupan rumah tangga perkotaan Jakarta pada periode 1950-an. Majalah-majalah ini menampilan banyak persoalan rumah tangga mulai dari masalah sosial, kesadaran politik, manual-manual yang membantu untuk mengatur rumah tangga, resep-resep makanan, serta berbagai informasi yang terkait dengan persoalan perempuan dan rumah tangga

\section{HASIL DAN PEMBAHASAN}

1. Budaya Modern dan Masyarakat Urban Jakarta pada Periode 1950-an

Memasuki periode tahun 1950-an masyarakat Indonesia berada dalam suatu periode transisi. Masa peralihan dari periode perang ke masa kemerdekaan membawa perubahan dalam setiap sendi kehidupan berbangsa dan bernegara. Masyarakat Indonesia, terutama yang tinggal di perkotaaan ketika itu berada dalam kondisi yang begitu berat akibat hancurnya pemukiman penduduk, sarana perkantoran, gedung-gedung pemerintahan, fasilitas umum, dan ruangruang rekreasi. Namun periode ini juga membawa harapan baru yakni bahwa mulai saat ini Bangsa Indonesia telah merdeka dan memiliki hak untuk menentukan nasibnya sendiri.

Perang Korea 1950-1953 membawa keuntungan bagi Indonesia. Peningkatan ekspor terutama permintaan akan minyak bumi dan karet menjadi modal awal bagi Indonesia dalam membangun diri setelah masa perang. Berbagai gedung pemerintahan, fasilitas dan sarana umum, sarana pemukiman kembali dibangun dan diperbaiki. Namun, kondisi ini hanya berlangsung sangat singkat, karena memasuki pertengahan 1950-an terjadi stagnasi ekonomi akibat konflik IndonesiaBelanda akibat masalah nasionalisasi perusahaan Belanda dan masalah Irian Barat.

Revolusi sosial yang terjadi pada masa Pendudukan Jepang dan Perang kemerdekaan telah menyebabkan terjadinya transformasi dalam lapisan sosial masyarakat. Masyarakat kelas menengah yang pada masa kolonial Belanda didominasi oleh Masyarakat Eropa, ningrat bumiputera, dan pegawai negeri, kini didominasi oleh para pegawai negeri dan birokrat lokal di tingkat daerah, pengusaha Tionghoa dan Bumiputera, jurnalis, dan pegawai-pegawai perusahaan (Vickers, 2005: 115-116)

Berbeda dengan yang terjadi pada masa kolonial saat pembangunan infrastruktur dan fasilitas publik lebih diutamakan. Pada masa 1950-an, pemerintah lebih banyak membangun fasilitas perumahan terutama untuk masyarakat kelas menengah. Menurut Freek Colombijn pembangunan ini sebagai usaha pemerintah untuk mendorong pertumbuhan kelas menengah perkotaan (Colombijn, 2011:437). Hal in sangat penting karena peran kelas menengah sangat membantu dalam peningkatan pertumbuhan ekonomi di perkotaan.

Pertumbuhan kelas menengah perkotaan bumiputera terutama pada 
periode awal 1950-an, didorong oleh terjadinya transisi dari para pekerja sektoral dan pegawai negeri yang sebelumnya diisi oleh orang-orang Eropa. Hal ini juga kemudian didukung oleh meningkatnya urbanisasi terutama di kotakota besar seperti Jakarta, Bandung, Medan, dan Surabaya. Pada masa inilah terjadi proses terjadinya akulturasi budaya. Kota menjadi sebuah ruang terbentuknya budaya urban pada masa pasca kemerdekaan. Bila di masa lalu akulturasi terjadi antara budaya barat dan timur, pada peride 1950-an akulturasi berkembang karena interaksi etnis yang hidup di wilayah perkotaan.

Hal yang menarik pada tahun 1950an terjadi pada perubahan gaya hidup masyarakat perkotaan. Meskipun kondisi Indonesia secara umum tidaklah baik, karena krisis ekonomi, perang saudara, konflik Indonesia-Belanda, dan lemahnya sistem pemerintahan, namun dalam pengaplikasian gaya hidup perkotaan halhal tersebut tidaklah terlalu memberikan pengaruh.

Menurut Adrian Vickers (2005: 127), media massa pada periode 1950-an memainkan peran penting dalam mempromosikan gaya hidup baru yang sesuai dengan perkembangan zaman Atom. Dalam media massa pada periode itu terpampang jelas mengenai bentuk ideal dari gaya hidup yang sesuai dengan perkembangan zaman. Pada periode ini bukanlah hal yang mengherankan jika mode pakaian terbaru dibahas dalam siaran radio maupun artikel dalam media massa. Gaya pakaian seperti menggunakan kaca mata hitam, memakai terusan (bagi wanita) atau jas (bagi pria) bukanlah hal yang luar biasa pada masa itu.

Berbagai restoran, bioskop, dan hotel menawarkan berbagai fasilitas makanan mewah, dansa dansi, pertunjukan drama, dan film yang disesuaikan dengan tingkat ekonomi para pengunjungnya. Penerapan budaya barat dalam bentuk arsitektur rumah, tata ruang rumah, cara makan, penggunaan kendaraan bermotor, pariwisata, berolahraga di klub olahraga, belanja, dan lainnya menjadi perilaku yang kerap terjadi dan berlangsung pada masa itu (Vickers, 2005: 127).

Perkembangan budaya glamour yang terjadi di periode ini pun rupanya seiring dengan meningkatnya kemiskinan yang terjadi di perkotaan. Konflik yang terjadi memaksa para penduduk pedesaan melakukan urbanisasi ke kota untuk menghindari menjadi korban dan terutama mencari kesempatan ekonomi di perkotaan akibat tidak stabilnya kondisi sosial politik di pedesaaan.

Kehidupan perkotaan Jakarta pada periode ini memamg penuh dengan dinamika. Periode ini dapat dikatakan sebagai sebuah proses pembentukan Indonesia. Interaksi sosial budaya yang terjadi di lingkungan masyarakat urban menciptakan sekat-sekat sosial budaya yang saling memengaruhi di masa kemudian. Periode ini merupakan periode yang sangat menarik karena pada periode inilah identitas pasca-kolonial Indonesia sebagai sebuah bangsa mulai terbentuk dan tercipta

Perkembangan masyarakat perkotaan Jakarta pada 1950-an mulai bergerak pada bentuk kesadaran akan pentingnya penerapan nilai dan pandangan modernitas. Modernisasi yang terjadi ada periode 1950-an berbeda dengan yang terjadi pada periode akhir kolonial. Bila pada periode akhir kolonial pelaku modernitas hanya pada kalangan kelas sosial menengah ke atas dan terbatas pada lingkungan daerah sub-urban perkotaan. Sementara itu pada 1950-an pelaku modernitas menyangkut semua lapisan masyarakat dan mencakup segala segi kehidupan mulai dari mentalitas, intelektualitas, dan gaya hidup. Perubahan ini terjadi sebab pada tahun 1950-an modernisme tidak dipandang lagi sebagai bagian dari high culture (budaya adiluhung) yang menempatkan modernisme sebagai produk budaya mewah, serta hanya dinikmati oleh kalangan kelas sosial tertentu, seperti pada 
masa kolonial. Modernisme pada tahun 1950-an merupakan bagian dari budaya massa, sehingga menjadi bagian dari produk konsumsi keseharian dan diterapkan oleh seluruh lapisan masyarakat. ${ }^{3}$

Pemahaman tentang nilai-nilai modernisme dalam gaya hidup dan rumah tangga para perempuan di Jakarta didukung oleh peran media cetak, reklame, dan lembaga pendidikan formal pada saat itu. Henk Schuldte Nordholt mengatakan bahwa proses ini merupakan bagian dari yang disebut sebagai education of desireyang ia kutip dari Ann Stoler-mengenai aturan-aturan gaya hidup modern. Education of desire ini merupakan pengetahuan mengenai gaya hidup modern yang diperoleh oleh kalangan kelas menengah dari media cetak, reklame, dan lembaga pendidikan formal (Nordholt, 2009, 109-114).

3 Budaya elite mempunyai ciri: (1) pemilik tetap menjadi pelaku (subjek budaya): (2) pelaku tidak mengalami alienasi, dan jati dirinya tetap; serta (3) pelaku pengalami pencerdasan. Ciri-ciri budaya massa adalah kebalikan dari budaya elite. Yaitu: (1) objektivasi; (2) alienasi; dan (3) pembodohan. Objektivasi artinya pemilik hanya menjadi objek, yaitu penderita yang tidak mempunyai peran apa-apa dalam pembentukan simbol budaya. la hanya menerima produk budaya sebagai barang jadi yang tidak boleh berperan dalam bentuk apa pun.Kuntowijoyo, "Budaya Elite dan Budaya Massa", dalam Idi Subandi, Life Style Ecstasy (Jakarta, 2009: 10).

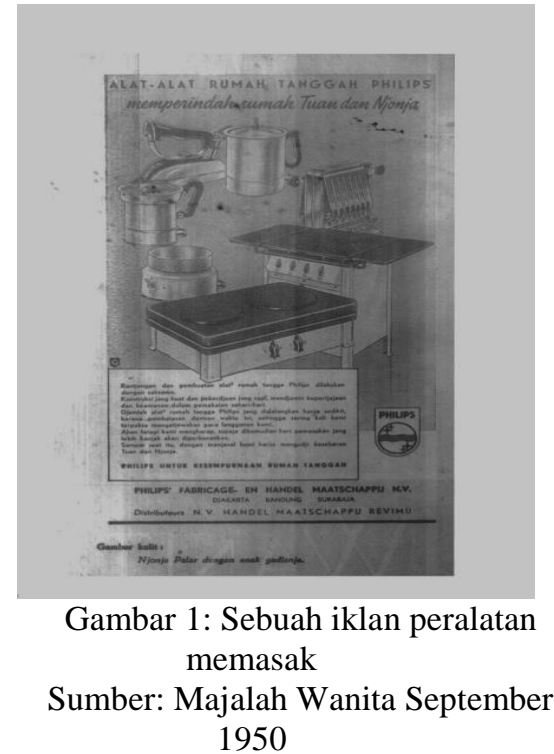

Melalui media cetak, reklame, dan lembaga pendidikan formal tercipta suatu bentuk pemahaman nilai-nilai modern dalam bentuk budaya material, personifikasi gaya hidup, pembentukan keluarga ideal, dan penciptaan simbolisme modern yang juga memiliki peran mendukung perluasan konsumsi dalam masyarakat.

Dalam bukunya "A History of Modern Indonesia", Adrian Vickers (2005: 127-129) menyatakan bahwa perkembangan modernisme di Indonesia pada 1950-an ditentukan oleh dua faktor yakni ekspansi produk modern karena dibukanya berbagai industri yang memproduksi barang dan produk modern, serta perkembangan media massa, seperti majalah, koran, dan radio yang menyiarkan tentang berbagai ornamen kehidupan masyarakat modern.

Produksi budaya modern dilakukan secara besar-besaran oleh pelaku industri pada saat itu yang didukung media massa, sehingga kehadiran media massa sangat berperan dalam proses education of desire budaya modern pada periode ini. Berbagai produk mulai dari pakaian, furniture, kitchen set, makanan dalam kemasan, dan lainnya diperkenalkan dan diulas melalui media massa sebagai bentuk ideal yang wajib dikenakan oleh modern citizen. 
Sehingga melalui kedua proses ini budaya modern menjadi bagian dari keseharian pada periode tersebut (Vickers, 2005: 127).

\section{Kehidupan Perempuan dan Rumah Tangga Urban Jakarta pada 1950-an}

Pada periode tahun 1950-an para perempuan di Jakarta merupakan kelompok sosial yang sangat aktif, para perempuan ini banyak terjun dalam berbagai bidang seperti politik, organisasi sosial, pendidikan, berbagai lapangan pekerjaan, serta berbagai hal sehingga menurut pandangan pada saat itu mulai terjadi kesetaraan antara laki-laki dan perempuan. Kehidupan sosial perempuan pada periode 1950-an juga cukup menarik. Para perempuan pada periode ini tidak terikat pada peraturan adat yang mengekang kebebasan mereka. Kebiasan keluar rumah baik sendiri, maupun dengan teman-teman pria bukan merupakan suatu hal yang tabu. Perempuan-perempuan pada periode ini juga sangat aktif memanfaatkan waktu luang mereka untuk rekreasi, berorganisasi, keliling kota dengan mengendarai kendaraan sendiri, mengikuti kegiatan koperasi, pergi ke bioskop, berenang, main tenis, dan berbagai kegiatan lain di luar aktifitas pendidikan dan pekerjaan mereka. Berbagai aktivitas di luar rumah ini pun tidak terbatas pada suatu kelompok sosial tertentu, namun mencakup perempuan-perempuan dari berbagai lapisan kelas (Wanita, April 1950: 118-121).

Kebebasan yang diperoleh para perempuan modern periode 1950-an juga menimbulkan protes dan tekanan dari para generasi tua dan laki-laki. Mereka memandang berbagai kegiatan yang dilakukan oleh para perempuan ini telah jauh dari batas nilai-nilai budaya tradisional. Pandangan tentang wanita modern pada periode ini adalah perempuan yang mandiri namun tetap dalam koridor perempuan yang ideal dalam rumah tangga. Kemampuan pendidikan, kreativitas, ketrampilan, dan pemikiran yang mereka miliki harus digunakan sebaik mungkin demi kepentingan keluarga. Perempuan juga harus menjaga kodrat mereka sebagai seorang istri dan ibu (Wanita, Maret 1951: 68).

Media massa disamping menampilkan manual mengenai gaya hidup baru bagi para perempuan, juga menunjukkan cara untuk menjadi perempuan yang ideal dalam rumah tangga dan bagi para suami. Perempuan yang ideal harus mampu pandai memasak, suka memanjakan suami, dapat membagi waktu antara keluarga dan pekerjaan, menghargai suami, serta menyesuaikan diri dengan kebiasaan dan hobi suami (Wanita, Juli 1959: 7).

Pandangan tradisional tentang peran perempuan sebagai ibu dan istri ideal dalam pandangan masyarakat patriarkis pada periode 1950-an merupakan sesuatu yang sulit dilakukan. Hal ini sering menimbulkan berbagai pertentangan dengan alasan kemajuan zaman dan perkembangan pendidikan yang berpandangan bahwa harus terdapat kesetaraan gender dan saling menghargai peran laki-laki dan perempuan; serta, kesulitan ekonomi pada tahun 1950-an yang menuntut lebih peran wanita untuk turut aktif dalam memeroleh pendapatan bagi keluarga. Kedua alasan ini kemudian meningkatkan posisi tawar sebagian perempuan untuk lepas dari peran klasik mereka dalam lingkungan domestik rumah tangga.

\section{Perkembangan Budaya Makan dalam Lingkungan Rumah Tangga Urban}

Ibu rumah tangga di perkotaan Jakarta pada tahun 1950-an harus memiliki kepandaian dalam mengatur ekonomi rumah tangganya terutama dalam persoalan yang menyangkut ekonomi dapur. Kondisi ekonomi yang sulit pada periode ini memaksa para ibu rumah tangga untuk seefisien mungkin mengatur pengeluaran rumah tangga. Para ibu rumah tangga ini harus pandai membuat perhitungan belanja yang disesuaikan dengan jumlah individu dalam setiap 
rumah tangganya. Dalam mengatur ekonomi dapurnya ibu-ibu rumah di perkotaan Jakarta juga membuat jadwal sajian harian dalam rumah tangganya. Penjadwalan sajian makan ini dilakukan setiap minggu, selain untuk memberikan variasi jenis masakan yang disajikan setiap hari juga mempermudah pengaturan pengeluaran untuk sajian makanan di dapur mereka. Jadwal makanan mingguan ini selain dibuat sendiri juga terdapat dalam majalah-majalah rumah tangga beserta resep-resepnya (Wanita, Januari 1950: 26).

Hal ini sangat berbeda dengan kondisi pada masa periode akhir kolonial. Pada masa akhir kolonial segala urusan rumah tangga dipegang dan dipercayakan kepada babu (pembantu perempuan). Pada masa kolonial ibu-ibu rumah tangga terutama yang hidup di kawasan sub-urban perkotaan menghabiskan waktu mereka untuk menikmati kehidupan yang santai. Kehidupan ibu rumah tangga kelas menengah pada masa kolonial dihabiskan dengan mengobrol, berbelanja, bergosip, bermain kartu, aktif dalam kegatan seni terutama seni-seni dari Eropa, piknik, ke bioskop, dan segala lain yang terkait dengan prestise pemenuhan gaya hidup. Mereka membiarkan para pembantunya untuk menyiapkan segala urusan rumah tangga mulai dari memasak, berbelanja, menyiapkan makanan, membersihkan rumah, merawat tanaman, dan mengawasi anak-anak mereka (Ariwibowo, 2011, 125).

Resep-resep yang disajikan dalam media massa di daerah perkotaan Jakarta pada awal tahun 1950-an tidak jauh berbeda dengan resep-resep yang disajikan pada masa akhir kolonial. Menu-menu masakan dari Eropa, peranakan, dan pribumi ditampilkan secara berkala dalam majalah-majalah tersebut. Hal yang cukup menarik dari pekembangan resep makanan pada periode 1950-an adalah semakin banyaknya resep-resep dari berbagai makanan yang berasal dari daaerah dan kelompok budaya lain di Indonesia seperti
Aceh, Manado, Kalimantan, Minangkabau, Palembang Arab, Bali, Banten, Betawi, dan lainnya. Perkenalan sajian makan dari daerah lain ini merupakan hal yang baru pada periode 1950-an. Sebab, pada periode akhir kolonial menu-menu yang disajikan dalam media massa adalah menu-menu populer yang biasa dinikmati oleh masyarakat perkotaan, serta biasa menjadi sajian dalam pesta dan sajian rijsttafel (Tropen Museum, Weerzen Met Indie: Eten en Drinken, tt: 322-324).

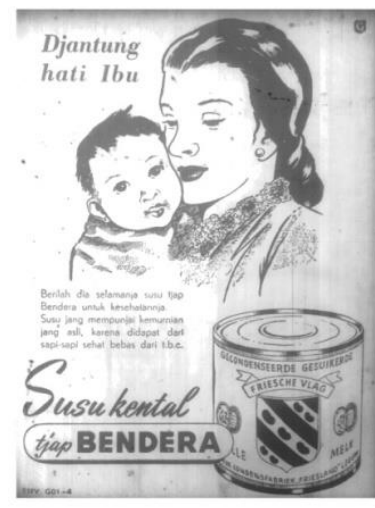

Gambar 2: Sebuah iklan susu

Sumber: Majalah Wanita edisi Desember 1951

Perkenalan menu-menu makanan dari berbagai daerah dan unsur kebudayaan di perkotaan Jakarta, juga tidak lepas dari semakin beragamnya etnis yang hadir di perkotaan Jakarta pada 1950-an. Interaksi sosial masyarakat urban perkotaan pada periode ini telah menanggalkan batasanbatasan lapisan ekonomi dan kelas sosial, menyebabkan terjadinya pembauran kebudayaan di daerah perkotaan. Kesempatan ekonomi yang terbuka pada lingkungan mayarakat perkotaan, menumbuhkan berbagai rumah makan yang membawa identitas kebudayaan dari kelompok etnis yang membuka rumah makan tersebut. Rumah makan Sunda, Padang, Batak, Tegal, Madura, Tionghoa, dan lainnya semakin tumbuh dan berkembang pada periode ini. Melalui proses ini maka tidak mengherankan aneka jenis makanan seperti rendang, gulai, nasi kebuli, martabak, Soto Banjar, Sate Madura, empek-empek, mie ayam, bakso, 
lalap, semur, dan lainnya menjadi sajian makan yang kerap kali disantap oleh masyarakat perkotaan (Tropen Museum, Weerzen Met Indie: Eten en Drinken, $\mathrm{tt}$ : 322-324).

Hal yang menarik dari perkenalan budaya makan ini adalah proses pengenalan makanan Tionghoa kepada etnis pribumi yang mayoritas beragama Islam. Makanan-makanan Tionghoa pada periode 1950-an sebagian besar mengandung olahan daging babi dan minyak babi, hal ini tentu diharamkan oleh Agama Islam, sedangkan para penganutnya sangat menyukai makanan Tionghoa tersebut. Maka untuk mengatasi hal ini dibuat altenatif lain yakni mengganti semua bahan yang mengandung daging babi tadi dengan bahan-bahan yang terbuat dari daging sapi atau daging ayam (Wanita, Agustus 1952: 312-313).

Makanan Tionghoa sebelumnya diperkenalkan ke dalam citarasa masakan di Jakarta berawal dari mulai masuknya para pendatang Tionghoa. Para pendatang ini pada awalnya mencoba makananmakanan setempat, namun kemudian tidak cocok dengan lidah mereka. Ketika mereka berusaha untuk membuat makananmakanan Tionghoa yang berasal dari negara induk mereka, mereka mengalami kesulitan sebab ada beberapa bahan baku yang sulit di dapatkan di Jakarta, sehingga kemudian mereka mulai membuat makanan-makanan Tionghoa dari bahanbahan lokal yang mudah ditemui.

Para pendatang dari Tionghoa ini kemudian juga banyak yang menikah dengan penduduk lokal, sehingga kemudian terjadi akulturasi citarasa, sehingga kemudian di Hindia dapat ditemui berbagai makanan olahan para orang Tionghoa peranakan ini, antara lain kecap manis, ${ }^{4}$ tauco, aneka olahan tahu

4 Kecap manis merupakan salah satu menu akulturasi citarasa budaya Tionghoa dan Jawa yang sangat khas dan berasal dari cerita yang menarik. Pada awalnya kecap yang ada di Jawa berasa asin, sesuai dengan yang terdapat di Negeri China. Namun mengalami modifikasi lokal-tahu pong, tahu sumedang, tahu serpong, dan beberapa jenis tahu lain, yang bersifat lokal, serta beberapa jenis masakan lain yang meskipun memiliki nama yang sama, namun memiliki perbedaan rasa, bahan baku dan pengolahan di beberapa daerah. Makanan Tionghoa ini juga diperkenalkan melalui beberapa peristiwa unik seperti makanan-makanan persembahan yang dibagi-bagikan pada rakyat kecil, kemudian menjadi panganan favorit masyarakat pribumi, seperti misalnya: bacang, sekoteng, dan wedang ronde.

Perkembangan rumah makan ini juga didorong oleh semakin terbatasnya waktu untuk mengkonsumsi makanan di rumah, sebab berbagai kesibukan dan aktivitas pekerjaan masyarakat perkotaan. Rumah makan-rumah makan yang bersifat etnis ini termasuk dalam tipologi rumah makan yang menyediakan sajian makan yang cepat dan praktis. Rumah makan ini terdapat di sekitar pemukiman padat penduduk (kampong), daerah komersial perkotaan, dan sekitar pusat aktivitas ekonomi dan industri. Para pengunjung rumah makan ini sebagian besar adalah kelas pekerja yang cukup sibuk dengan aktivitas pekerjaan mereka sehingga sulit

rasa melalui perkawinan para imigran Tionghoa ini dengan penduduk pribumi yang lebih menyukai rasa manis. Kemudian muncullah kecap manis di Jawa di Negeri China sendiri kecap yang terdapat di sana adalah kecap asin, bahkan hingga saat ini. Catenius van der Meijden juga mencatat bahwa kecap yang paling terkenal pada awal abad ke20 adalah "Ketjap-benteng" yang berasal dari Tangerang. Kecap ini bahkan telah diekspor ke Belanda pada saat itu. Kota Tangerang hingga saat ini pun masih identik dengan "Kecap Benteng", meskipun kecap ini sudah tidak diproduksi kembali. Komunitas Lintas Budaya Indonesia, Peranakan Tionghoa di Indonesia: Sebuah Penjelasan Budaya (Intisari, 2009: 224; Catenius van der Meijedn, 1904: 90).

5 Makanan-makanan ini basanya disajikan dalam acara-acara ibadat Puchan Tangceh, dan lainnya (Intisari, 2009: 225-226). 
menyediakan waktu untuk sarapan dan makan siang di rumah. Kehadiran rumah makan ini menjadi solusi efektif, sebab mampu menjadi sarana kebutuhan makan kelas pekerja ini di antara waktu kerja mereka yang padat, rumah makan juga menjadi ruang interaksi sosial antarmasyarakat kelas pekerja, seperti membicarakan kejadian-kejadian yang terjadi di sekitar kota.

Sebelum melakukan aktivitas pekerjaan, ibu rumah tangga harus menyiapkan sajian sarapan bagi seluruh keluarga. Di pagi hari ibu rumah tangga akan menyajikan sarapan berupa nasi goreng, bubur, roti, dan telur, atau bila tidak sempat menyajian sarapan mereka akan membeli di warung-warung makan yang berada di sekitar rumah. Pada siang hari biasanya disajikan makanan berupa nasi disertai lauk pauk dan sayur, terkadang juga disajikan buah-buahan. Makanan yang disajikan pada siang hari antara lain aneka jenis sup (sup ayam, sup jagung, sup, daging, sup buntut, dan lainnya), sayur bayam, aneka jenis sambal (sambal terasi, sambal kelapa, sambal goreng, sambal bajak, dan lainnya) beserta lalapan, perkedel, ikan goreng, ayam goreng, tempe, tahu dan lainnya (Wanita, Desember 1950: 448; Wanita, Oktober, 1951: 57).

Pada sore harinya menjelang adzan Maghrib, ketika seluruh anggota keluarga telah berkumpul bersama selepas aktivtas sekolah dan pekerjaan akan disajikan teh dan aneka makanan kecil. Makanan kecil yang disajikan biasanya berupa jajanan pasar seperti onde-onde, klepon, ketimus, pisang goreng, singkong goreng, dan lainnya (Wanita, Maret 1951: 89).

Pada malam hari akan disajikan makanan pada siang hari yang masih tersisa atau akan pergi bersama untuk makan di restoran atau rumah makan. Penyajian makan dengan metode seperti ini merupakan kelanjutan budaya makan dalm lingkungan rumah tangga pada masa kolonial.
Pada masa kolonial penyajian makanan dalam rumah tangga pada lingkungan keluarga urban kelas menengah biasanya disiapkan oleh para koki, babu, dan jongos. Kesulitan ekonomi dan penghematan yang dilakukan oleh para keluarga di masa 1950-an memaksa mereka untuk paling tidak hanya memiliki seorang pembantu yang harus menyiapkan segala hal mulai dari mencuci, memasak, menjahit, membereskan rumah, dan lainnya. Bagi keluarga kelas menengah yang cukup mampu mereka biasanya akan merekrut pembantu yang berasal dari Sekolah Kepandaian Putri (SKP). Para pembantu yang berasal dari sekolah ini biasanya termasuk tenaga kerja terampil dan memang dipersiapkan untuk terlibat dalam aktivitas pekerjaan rumah tangga.

Sekolah Kepandaian Putri (SKP) merupakan sebuah sekolah yang mengajarkan mengenai keterampilan dalam mengurus rumah tangga. SKP merupakan sekolah setingkat dengan Sekolah Lanjutan Atas dengan masa studi selama tiga tahun. Sekolah ini merupakan kelanjutan dan pengembangan dari Huishoudschool pada masa kolonial Belanda. Dalam SKP diajarkan berbagai keterampilan rumah tangga seperti, memasak, menjahit, mencuci dan setrika, mengatur dan membereskan rumah, serta menyiapkan jamuan pesta. Di samping berbagai keterampilan SKP juga mengajarkan mengenai kemampuan pendidikan dasar seperti bahasa Indonesia, Bahasa Inggris, berhitung, akutansi, sejarah, dan lainnya. Pendidikan memasak yang diajarkan dalam SKP mencakup sajian makanan Indonesia dan makanan asing.

Pendidikan dan pelatihan memasak bagi para ibu rumah tangga di samping melalui manual-manual dalam buku masakan dan media massa, juga melalui berbagai kursus dan demonstrasi memasak. Kursus dan demo memasak ini biasanya digelar di sebuah rumah milik seorang nyonya yang menawarkan jasa kursus atau di rumah milik seseorang yang 
mengundang kerabatnya untuk belajar memasak dengan mengundang seorang juru masak. Penawaran jasa kursus memasak ini biasanya melalui iklan dalam media cetak, seperti dalam majalah "Huisvrouw in Indonesie" yang setiap bulan selalu menyediakan jadwal kursus memasak di beberapa tempat. Dalam salah satu kegiatan kursus memasak pada tahun 1952 biaya yag dikeluarkan berkisar antara Rp 3,50 hingga Rp 5,00 sekali pertemuan, serta diadakan dua kali dalam sebulan. Jenis masakan yang dipraktikkan biasanya merupakan jenis masakan-masakan Eropa, Tionghoa, dan pribumi Huisvrouw in Indonesie, Agustus-September 1952: 15). Kursus dan demonstrasi memasak juga digelar sebagai media promosi suatu produk bahan makanan seperti mentega, minyak goreng, kornet, dan lainnya, seperti yang digelar oleh produsen mentega "Palmboom" dan minyak goreng "Delfia" (Huisvrouw in Indonesie, September 1950: 15).

Selain kursus memasak yang digelar oleh individu atau kelompok sosial tertentu, juga terdapat kursus keterampilan memasak yang dikelola oleh sebuah lembaga pendidikan semi formal. Kursus memasak di lembaga pendidikan ini berlangsung selama 8 bulan dengan satu kali pertemuan setiap minggunya. Biaya yang dikeluarkan oleh peserta per bulan sekitar Rp. 60,00 untuk kursus memasak dan Rp. 50,00 untuk membuat kue. Pengelola kursus ini menyatakan bahwa lembaga kursus yang didirikannya tidak saja berupaya untuk menambah pengetahuan memasak bagi para muridnya, namun juga merupakan mengajarkan alternatif bagi para murid untuk mengembangkan industri makanan sebagai usaha untuk menambah pemasukan bagi keluarga (Wanita, Februari 1954: 86-87)

Kenaikan berbagai bahan kebutuhan pokok semenjak pertengahan dekade 1950an, juga berdampak pada kenaikan harga makanan dalam kemasan. Makanan dalam kemasan berkembang di Indonesia semenjak periode 1930an sebagai salah satu alternatif daam menyajikan makanan yang praktis dan efisien di tengah gejolak kenaikan harga bahan pangan selepas krisis ekonomi 1930 (Schoulten, 2000: 142). Sebagai salah satu alternatif untuk menekan pengeluaran rumah tangga akibat semakin tinggi harga kebutuhan pangan, maka diadakan kursus membuat maknan dalam kemasan yang diadakan oleh Lembaga Makanan Rakjat (LMR). Kursus ini mengajarkan mengenai cara membuat aneka jenis produk makanan dalam kemasan seperti selai, ikan dalam botol, acar, udang kering, buah-buah kering, sari buah, kecap. Tauco, saus tomat, agar-agar, susu kedelai, dan lainya (Huisvrouw in Indonesie, Januari 1955: 21-23).

Fenomena yang cukup menarik dari perkembangan budaya makan pada tahun 1950-an adalah mulai diadakan konteskontes memasak. Kegiatan kontes-kontes kerap kali diadakan pada periode tahun 1950-an. Berbagai kontes yang digelar pada periode ini, antara lain: kontes busana, kontes menghias bunga, kontes kecantikan, hingga kontes mirip artis. Kontes memasak ini mencakup kontes memasak makanan, membuat kue, menghias kue, dan menyajikan makanan dalam meja makan. Salah satunya kontes yang digelar adalah kontes memasak yang diadakan pada tahun 1954 di Gelanggang Dagang Wanita. Kontes ini diikuti oeh 18 peserta dan salah satunya adalah laki-laki. Para peserta harus menyajikan makanan dari menu pembuka, menu utama, dan menu penutup, serta lengkap dengan penyajiannya dalam meja makan. Pemenang kontes memasak ini mendapatkan hadiah utama berupa satu set kompor gas (Wanita, Maret 1954: 140)

Para keluarga di tahun 1950-an kerap kali juga mengadakan jamuanjamuan pesta yang digelar di rumah mereka. Seperti pada masa kolonial, pesta yang digelar lebih untuk menunjukkan prestise dan status sosial, sehingga dalam pesta ini pun yang diundang adalah kerabat dari kelas sosial yang sama atau sederajat. Para tamu yang diundang, di samping 
mendapatkan undangan dari tuan rumah juga diberikan daftar menu yang akan disajikan dalam pesta tersebut, serta memo hadir atau tidaknya sang tamu. Memo ini kemudian dikirimkan ke tuan rumah sehingga, tuan rumah dapat memperkirakan jumlah tamu yang hadir. Tuan rumah juga harus menyiapkan segala sesuatunya dengan cara yang terbaik. Persiapan ini tidak saja terbatas pada menu makanan yang hendak disajikan, melainkan juga pada pengaturan meja makan, interior rumah, dan pengaturan pergantian menu makan. Dalam membantu pekerjaan untuk menyiapkan pesta ini, tuan rumah juga dilayani oleh para pembantu yang biasanya merupakan lulusan dari Sekolah Kepandaian Putri, sehingga mereka juga telah memahami dalam pengaturan suatu pesta (Wanita, Mei 1951: 204-205).

Periode 1950-an yang identik dengan perkembangan teknologi dalam rumah tangga yang memberikan berbagai kemudahan, turut memberikan pengaruh pada perkembangan budaya makan dan sajian makanan. Kulkas, kompor minyak, kompor gas, oven, mixer, dan lainnya kini semakin banyak digunakan dalam lingkungan rumah tangga. Memasak bukan lagi sesuatu yang merepotkan seperti pada masa sebelumnya. Sebagian teknologi ini memang telah muncul pada periode akhir kolonial, namun penggunaannya hanya terbatas pada kalangan kelas sosial tertentu. Sedangkan pada peiode 1950 dalam setiap rumah tangga kelas menengah perkotaan pasti memiliki paling tidak kompor minyak. Edukasi dan propaganda makanan sehat juga turut mengangkat konsumsi produk-prosuk teknologi memasak ini, di samping promosi iklan dalam berbgai media massa (Wanita, April 1950: 118-121).

\section{Kesadaran Gizi dan Pengembangan Makanan Alternatif}

Fenomena perkembangan budaya makan di Indonesia pada periode tahun 1950-an-di samping gaya hidup dan penyajian makanan - adalah munculnya kesadaran gizi dan kesehatan. Fenomena ini cukup menarik, kesadaran terhadap gizi yang terkandung dalam makanan sebenarnya telah mulai ada sekitar pertengahan 1930-an seiring dengan berdirinya Lembaga Makanan Rakjat (LMR) pada tahun 1937. Pada tahun 1948, pada masa sesudah kemerdekaan lembaga ini berada di bawah Departemen Kesehatan Republik Indonesia. LMR merupakan suatu lembaga yang bertugas menyelenggarakan penyelidikanpenyelidikan dan memberi petunjukpetunjuk tentang segala sesuatu yang mengenai makanan, yang menuju kesempurnaan makanan rakyat, serta usaha membuat melek gizi (Nutrition minded) pada masyarakat (Wanita, Oktober 1953: 422). ${ }^{6}$

Pada tahun 1952 LMR dipimpin oleh Prof. DR. dr. Poerwo Soedarmo yang juga dikenal sebagai "Bapak Gizi Indonesia". Poerwo Soedarmo mendapatkan tugas yang berat pada periode awal republik untuk memperbaiki kualitas gizi dan memperkenalkan makanan yang seimbang pada masyarakat Indonesia. Kondisi ekonomi yang buruk ditambah dengan pola makan yang buruk menjadi persoalan rendahnya tingkat kesehatan masyarakat pada periode 1950an. Masih rendahnya kesadaran tentang kesehatan pada periode ini bukan saja menjadi persoalan masyarakat kelas bawah, melainkan juga masyarakat kelas atas. Masyarakat kalangan atas perkotaan Jakarta banyak yang terjangkit obesitas sehingga mengakibatkan banyak mengalami berbagai gangguan kesehatan sepert jantung, diabetes, hipertensi, dan lainnya (Huisvrouw in Indonesie, Agustus 1950: 7$)^{7}$

6 PP 71/ 1948 tentang Pekerjaan Susunan Pimpinan, dan Tugas Kewajiban Kementetrian Kesehatan.

${ }^{7}$ http://www.depkes.go.id/index.php?option=ne ws\&task=viewarticle $\&$ sid $=3319, \quad 2$ Januari 2011, 19:37 
Sebagai usaha untuk memperbaiki gizi masyarakat Indonesia maka Poerwo Soedarmo memperkenalkan slogan makanan "empat sehat dan lima sempurna" pada pertengahan tahun 1950an. Slogan tersebut mengacu pada slogan yang digunakan di Amerika Serikat pada tahun 1940-an, yang menekankan pada prinsip keseimbangan makanan, balance diet atau Pedoman Gizi Seimbang. Secara internasional, pedoman ini digambarkan dalam bentuk piramid, yang di Indonesia digambarkan sebagai "tumpeng". Proporsi terbesar, di bagian dasar tumpeng adalah kelompok karbohidrat sebagai sumber energi. Di atasnya, kelompok buah dan sayur sebagai sumber vitamin dan mineral. Pada lapisan ketiga,dengan proporsi lebih kecil lagi, ada kelompok lauk pauk sebagai sumber protein. Dan pada puncak tumpeng yang merupakan proporsi terkecil terdapat kelompok makanan yang dikonsumsi sedikit saja yaitu gula, minyak, lemak dan garam (Huisvrouw in Indonesie, Agustus 1950: 7).

Proses edukasi makanan "empat sehat dan lima sempurna" dilakukan melalui berbagai cara antara lain dengan melakukan propaganda makanan sehat di daerah perkampungan perkotaan dan daerah pedesaan, serta melalui berbagai media massa pada periode tersebut. Pekerjaan memperkenalkan budaya makan sehat dalam masyarakat dilakukan LMR bersama para siswi dari Sekolah Kepandaian Putri. Usaha Poerwo Soedarmo ini juga mendapatkan bantuan dana dari UNICEF. Di samping berupaya meningkatkan pasokan gizi bagi masyarakat, LMR juga mendorong agar kurikulum tentang gizi dan kesehatan diperkenalkan dalam sekolah dasar mulai dari tingkat Sekolah Lanjutan Pertama (Huisvrouw in Indonesie, Agustus 1950: 7).

LMR pada tahun 1951 juga membuat balai pelatihan bagi para calon ahli gizi. Balai pendidikan ini diberi nama Sekolah Ahli Diet yang merupakan sekolah semi akademis. Sekolah ini di samping mengajarkan tentang pemahaman gizi juga mengajarkan mengenai cara menyusun makanan yang memenuhi syarat-syarat kesehatan, memasak untuk orang banyak, menyusun makanan sehat untuk ibu hamil dan ibu menyusui, serta menanam tanaman dan memelihara ternak di pekarangan sebagai usaha meningkatkan pasokan gizi yang murah pada masyarakat (Wanita, Oktober 1953, hlm. 422-423).

Para siswa dari sekolah ini adalah lulusan dari Sekolah Kepandaian Putri dan Sekolah Lanjutan Atas bagian B. lama pendidikan di Sekolah Ahli Diet adalah selama 1,5 tahun, dengan 1 tahun pelatihan teori dan 6 bulan untuk praktik kerja lapangan. Para lulusan dari sekolah ini akan bekerja di Departemen Kesehatan sebagai juru penerangan makanan. Kewajiban seorang juru penerangan makanan adalah sebagai penyuluh gizi, memberikan kursus dan pelatihan memasak makanan sehat, dan mengadakan demonstrasi, serta pameran mengenai gizi dan makanan sehat (Huisvrouw in Indonesie, Agustus 1950: 7).

Program kesadaran gizi yang dilakukan oleh LMR juga berdampak pada semakin banyaknya kegiatan edukasi mengenai gizi dalam berbagai media massa perempuan. Para ibu rumah tangga diingatkan untuk menjaga pola makan sehat dan seimbang sehingga tidak mengalami kekurangan gizi dan obesitas. Syarat-syarat memasak yang baik yang diperkenalkan pada tahun 1950-an mencakup beberapa hal seperti: variasi sajian makanan yang teratur setiap hari sehingga tidak menimbulkan kebosanan dari suami dan anak-anak, cukup banyak mengadung zat-zat makanan, jumlah porsi makan yang cukup untuk sekeluarga, rasanya harus enak, banyak menggunakan bahan dasar sayur mayur, dan memenuhi syarat kebersihan (Wanita, Juli 1959: 13)

Semakin tingginya harga bahan pangan juga mengakibatkan semakin rendahnya konsumsi protein dan kalori bagi masyarakat, terutama dalam konsumsi produk hewani yang berasal dari susu, 
daging, dan ikan. Maka untuk mengatasi hal ini dibuat alternatif bahan makanan tersebut dari kacang kedelai. Pada periode ini makanan yang dibuat dari tempe, tahu, kecap tauco, dan susu kedelai banyak ditampilkan dalam resep-resep di media massa perempuan sebagai makanan alternatif pengganti daging (Huisvrouw in Indonesie, Agustus 1950: 7-8). Disamping itu juga terdapat alternatif makanan lain yang disusun oleh LMR dan Departmen Pertanian, seperti aneka makanan yang dibuat dari kacang-kacangan, umbiumbian, dan jagung sebagai alternatif pengganti beras (Depernas, 1960: 20).

\section{PENUTUP}

Education of Taste atau pendidikan selera yang terjadi di lingkungan rumah tangga perkotaan Jakarta pada periode 1950-an merupakan fenomena yang menarik. Bila pada periode akhir kolonial education of taste yang terjadi adalah pada proses pengedukasian selera lidah terhadap jenis-jenis makanan yang menyimbolkan status dan prestise sosial. Maka, pada periode 1950 -an proses pendidikan selera memengaruhi proses pembiasaan lidah terhadap jenis makanan yang sehat dan bergizi, di samping nilai-nilai simbolis dari makanan yang dikonsumsi.

Kondisi sosial, ekonomi, dan budaya pada periode 1950-an yang dinamis telah menyebabkan terjadinya proses penyesuaian lidah terhadap berbagai unsur citarasa baru. Perkembangan budaya barat, gejolak politik dan ekonomi, kesadaran nasionalisme, perkembangan pendidikan, dan kesadaran akan pentingnya kesehatan merupakan beberapa hal memengaruhi perkembangan pendidikan selera pada periode 1950-an.

Terdapat empat faktor yang memengaruhi proses perkembangan pendidikan selera pada lingkungan rumah tangga urban di perkotaan Jakarta. Faktor pertama adalah melalui pendidikan. Perkembangan bidang akademis di Jakarta pada 1950-an bukan hanya terbatas pada peningkatan kesadaran intelektual, namun juga pada peningkatan keterampilan individu yang berkembang seiring dengan peningkatan kualitas standar gaya hidup masyarakat. Berkembangnya budaya barat yang memiliki citra efisien, praktis, dan higienis dalam pandangan masyarakat perkotaan Jakarta saat itu membutuhkan suatu pelatihan ketrampilan yang memadai agar dapat dikatakan sebagai individu yang cakap dengan menerapkan standar hidup yang modern (modern citizen).

Sekolah Kepandaian Putri merupakan sekolah yang bukan hanya memberikan pelatihan memasak namun juga berupaya untuk meningkatkan kualitas perempuan Indonesia. Perempuan Indonesia tidak hanya mampu dalam halhal yang berkaitan dengan rumah tangga, namun juga memliki kemampuan intelektual yang memadai. Sehingga perempuan tidak hanya sekadar pandai memasak makanan yang, nikmat namun juga harus pandai memasak makanan sehat sehingga turut berperan dalam meningkatkan kualitas hidup manusia Indonesia.

Faktor kedua adalah melalui interaksi sosial dan kekerabatan yang terjalin antarrumah tangga urban di Jakarta. Pengenalan sajian makanan barat dengan menggunakan peralatan memasak yang modern. Selain melalui kegiatan pelatihan dalam sekolah dan kursus, juga melalui interaksi sosial antarmasyarakat perkotaan. Pengenalan makanan biasanya juga dilakukan melalui pertukaran makanan antarkerabat dan saling membagi resep dari makanan yang disajkan. Kehidupan keluarga urban yang biasa melakukan kegiatan kumpul bersama antar kerabat maupun kelompok sosial seperti perkumpulan, koperasi, atau organisasi perempuan di samping membahas berbagai kegiatan politis, juga dimanfaatkan sebagai media education of taste. Pemanfatan organsasi sosial perempuan ini dilakukan dengan mengundang kegiatan demo memasak atau melakukan kunjungan ke sekolah-sekolah yang memberikan keterampilan memasak. 
Faktor ketiga adalah terjadinya perkembangan dalam industri pengolahan dan pengemasan makanan. Melalui perkembangan teknologi dalam industri pengolahan dan pengemasan makanan telah menyebabkan terjadinya perkembangan sajian masakan dalam rumah tangga. Makanan-makanan tertentu yang pada awalnya hanya disajikan berdasarkan musim panen, kini bisa disajikan setiap hari dalam meja makan. Perkembangan industri pengolahan dan pengemasan makanan juga menyebabkan semakin berkembangnya variasi jenis makanan akibat semakin bertambahnya bahan-bahan makanan yang praktis dan mudah digunakan seperti coklat bubuk, mentega, keju, susu bubuk, susu kental manis, aneka jenis sayuran, daging, dan ikan yang telah diolah dan dikemas dalam kaleng, serta lainnya, sehingga menjadikan proses penyajian masakan menjadi lebih mudah dan ringkas.

Perkembangan industri pengolahan dan pengemasan makanan merupakan tuntutan dari masyarakat modern terhadap segala sesuatu yang cepat dan ringkas, namun efektif. Masyarakat perkotaan modern yang sebagian besar merupakan masyarakat kelas pekerja, harus selalu membagi waktu mereka dengan urusan keluarga, pekerjaan, dan interaksi sosial antarkerabat, sehingga membuat segala sesuatunya harus diatur dan dikelola secara baik dan efisisen termasuk dalam urusan dapur.

Faktor keempat adalah melalui peran Lembaga Makanan Rakjat (LMR). LMR merupakan suatu lembaga milik pemerintah yang tidak saja berperan dalam kebijakan ketahanan pangan, namun juga menjadi lembaga yang mensosialisasikan makanan sehat. LMR sangat berpean dalam proses kasadaran gizi bagi masyarakat. Sehingga konsumsi makan menjadi tidak sembarangan serta hanya memerhatikan rasa, serta status simbolis yang terdapat pada makanan melainkan juga pada unsur kandungan nilai-nilai gizi. Pemahaman akan nilai kandungan gizi ini juga menyebabkan semakin berkembanganya konsumsi makanan seperti tempe, telur, tahu, ketela, susu kedelai,n jagung, dan lainya sebagai makanan alternatif yang sehat di tengah kesulitan ekonomi pada periode 1950-an.

Sajian makanan merupakan suatu produk kebudayaan yang dapat dilihat, dibagi, dan dikonsumsi, sebab penyajian makanan merupakan suatu hasil dan kreasi dari suatu kelompok masyarakat. Bahanbahan, persiapan dan penyajian makanan menunjukkan secara nyata suatu bentuk identitas dan pengalaman kultural dari setiap kelompok kebudayaan. Seperti bentuk kebudayaan lainnya (pakaian, bahasa, dan perayaan), makanan dapat memberikan suatu gambaran dan pengalaman setiap kelompok dalam merepresentasikan agama, etnis, status sosial, dan keunikan budaya yang mereka miliki. Dalam melihat budaya makan dan variasi jenis makanan sebagai produk konsumsi akan dapat disaksikan simbolisme makanan bagi suatu identitas kelompok masyarakat. Setiap makanan yang disajikan oleh setiap masyarakat akan menggambarkan mengenai budaya, nilai, dan sejarah dari suatu kelompok masyarakat, karena kebudayaan merupakan produk yang dihasilkan oleh masyarakat dari keseimbangan entitasentitas nilai yang menjadi pandangan hidup suatu masyarakat.

\section{DAFTAR SUMBER 1.Dokumen}

Anonim. 1960.

PP 71/ 1948: Tentang Pekerjaan Susunan Pimpinan, dan Tugas Kewajiban Kementerian Kesehatan. Seksi Industri Pangan Depernas. Suatu Laporan. Jakarta: Depernas.

Depernas. Seksi Industri Pangan. 1960. Suatu Laporan. Jakarta: Depernas.

\section{Buku dan Artikel}

Braudel, Fernand, 1980. Civilization and Capitalism $15^{\text {th }}-18^{\text {th }}$ Century: The Structure of Everyday 
Life: The Limits of The Possible. London: Colin/Fontana Press.

Catenius, van der Meijden. 1904.

Specerijen en ingredienten der rijsttafel herkomst, eenkoop, keuren bereinden endragen en Indisch Kreuden en verdere benoodigoheden voor de rijsttafel. SemarangSurabaja: van Dorp.

Colombijn, Freek. 2011.

"Public Housing in Post-Colonal Indonesia: The Revolution of Rising Expectation". Bijdragen tot de Taal, Land-en Volkenkunde, Vol. 167, no. 4, 2011, hlm. 437-458.

Komunitas Lintas Budaya Indonesia. 2009.

Peranakan Tionghoa di Indonesia: Sebuah Penjelasan Budaya. Jakarta: Intisari.

Kuntowijoyo. 2009.

"Budaya Elite dan Budaya Massa", dalam Idi Subandi, Life Style Ecstasy. Jakarta: Jalasutra.

Locher-Schoulten, Elsbeth, 2000.

Women and The Colonial State: Essays on Gender Community in The Netherlands Indies 1900-1942. Amsterdam: Amsterdam University Press.

Nordholt, Henk Schulte., 2009

"Onafhankelijke of Moderneit?: Een Geiilustreerde hypothese", dalam Marieke Bloembergen (ed.), Het Koloniale Beschavingsoffensief: Wegen naar het Nieuw Indie 18901950. Leiden: KITLV.

Vickers, Adrian. 2005.
A History of Modern Indonesia. Cambrigde: Cambridge University Press.

Weerzen Met Indie: Eten en Drinken. Gd.

Amsterdam: Waaders Uitgraven en Tropenmuseum.

\section{Tesis}

Ariwibowo, G. Andika. 2011.

Pendidikan Selera: Perkembangan Budaya Makan di Perkotaan Jawa pada Periode Akhir Kolonial. Tesis. Yogyakarta: Universitas Gadjah Mada.

\section{Majalah}

Huisvrouw in Indonesie, Agustus 1950.

Huisvrouw in Indonesie, September 1950.

Huisvrouw in Indonesie, Agustus 1952

Huisvrouw in Indonesie, Januari 1955.

Wanita, Januari 1950.

Wanita, April 1950.

Wanita, Desember 1950.

Wanita, Maret 1951.

Wanita, Mei 1951.

Wanita, Agustus 1952.

Wanita, Oktober, 1952.

Wanita, Oktober 1953.

Wanita, Februari 1954.

Wanita, Maret 1954.

Wanita, Juli 1959.

Wanita, Juli 1959

\section{Internet}

http://www.depkes.go.id/index.php?option=ne ws \& task $=$ viewarticle \& sid $=3319, \quad 2$ Januari 2011, 19:37 